\title{
MicroRNA Expression in the Progression and Aggressiveness of Papillary Thyroid Carcinoma
}

\author{
AGNIESZKA ZEMBSKA ${ }^{1}$, ALEKSANDRA JAWIARCZYK-PRZYBYŁOWSKA ${ }^{1}$, \\ BEATA WOJTCZAK ${ }^{2}$ and MAREK BOLANOWSKI ${ }^{1}$ \\ ${ }^{1}$ Department of Endocrinology, Diabetes and Isotope Therapy, Wroclaw Medical University, Wroclaw, Poland; \\ ${ }^{2}$ First Department of General, Gastroenterological and Endocrine Surgery, \\ Wroclaw Medical University, Wroclaw, Poland
}

\begin{abstract}
In the last two decades microRNAs have received great attention in research because of their ability to regulate gene expression. Many studies have shown that defects in different microRNA molecules are linked to many diseases; however, their contribution towards thyroid disease has not been fully explored. Herein, we present a short review of the present state of knowledge on microRNAs, such as their origin, their biogenesis and biological function, as well as their differential expression in papillary thyroid carcinoma. Dysregulated microRNA has been closely linked to thyroid dysfunction and oncogenicity leading to this type of thyroid cancer. The effects of Single Nucleotide Polymorphisms in microRNA are also discussed with respect to papillary thyroid carcinoma.
\end{abstract}

MicroRNAs (miRNA, miR) are a class of endogenous noncoding RNA molecules. Mature miRNAs are short, singlestranded RNA molecules ranging from 18 to 22 nucleotides in length (1). These molecules play a substantial role in the regulation of gene expression, through the induction of translational repression or silencing effects by complementary binding to target mRNAs (2-4). They may also act as tumor suppressor genes and oncogenes (5). Although miRNAs constitute only $3 \%$ of the human genome, it is believed that these molecules altogether regulate more than half of the protein-coding genes. Noteworthy, one single miRNA can alter the expression of hundreds of different

Correspondence to: Agnieszka Zembska, Department of Endocrinology, Diabetes and Isotope Therapy, Wroclaw Medical University, Wybrzeze Pasteura 4, 50-367 Wroclaw, Poland. Tel: +48 717842558, Fax: +48 713270957, e-mail: aga.zembska@gmail.com

Key Words: MicroRNA, circulating microRNA, gene expression, papillary thyroid cancer, SNP, review. transcripts (6). MiRNAs are expressed in a tissue-specific fashion (7) and can be found, apart from tissues, also in blood as components of serum, plasma, mononuclear cells and in other body fluids (i.e. urine, semen, saliva, tears, ascitic fluid, amniotic fluid and breast milk) (8, 9). Circulating miRNA molecules are very stable in the blood plasma and serum because they are incorporated in microparticles, such as exosomes and apoptotic bodies (10, 11). Biochemical analyses have revealed that miRNA is resistant to RNase activity as well as to extreme acidic and alkaline $\mathrm{pH}$ and temperature $(12,13)$.

\section{Biogenesis of microRNAs}

Briefly, biogenesis of miRNA is initiated by the generation of non-coding primary miRNA (pri-miRNA) transcripts (14). MiRNA is first transcribed as pri-miRNA by RNA polymerase II in the nucleus and then, split into precursor microRNA molecules (pre-miRNA) (15). Next, pre-miRNA is transported through exportin 5 (XPO5) to the cytoplasm where it is processed by the Dicer RNase III enzyme, to form mature miRNA $(16,17)$. Mature miRNAs can promote or inhibit mRNA translation and degradation by targeting with precision complementary sequences in 3'UnTranslated Regions (3'UTR) $(14,18)$. In this way, miRNAs modulate different cellular pathways and can be used as therapeutic means to treat pathological conditions, such as cancer (19).

\section{Discovery of microRNAs}

This novel class of small regulatory RNAs were first described in 1993 by Lee et al. in Caenorhabditis elegans (20). Since their discovery and original description in the 90s, the number of miRNA sequences deposited in the microRNA database (miRBase) has grown exponentially (21). Concomitant with this, the amount of research studies on 
miRNA has greatly increased, especially following the identification of miRNA in human blood in 2008 (22). This discovery generated vast interest for the potential use of plasma or serum miRNAs as biomarkers of neoplastic and non-neoplastic disease (23). To-date more than 2,800 miRNA sequences have been recorded in the miRBase, which acts as a public repository for miRNAs (24).

\section{Function of microRNAs}

MiRNA is involved in regulating almost all biological processes, including cell proliferation, differentiation, apoptosis, hematopoiesis, stress responses and metabolism $(1,25)$. Recent findings demonstrate a crucial role for certain miRNA molecules in immune cell differentiation and immune responses (26-28), making them very relevant for the progression of many diseases, including tumors (29). MiRNA molecules have been shown to act both as posttranscriptional regulators of gene expression and as messengers of intercellular signaling (30). Encapsulated within exosomes and other microvesicles, or bound to complexes with proteins, miRNAs are secreted into the extracellular space, where they can be transported to both neighboring and distant cells, infiltrate biological fluids, and travel throughout the whole organism, where they can exert their regulatory role on different processes (31).

\section{MicroRNA as a Promising Biomarker}

MiRNA is a promising biomarker in many diseases, as various cell-free circulating miRNA molecules have been found to be dysfunctional in cancers $(32,33)$, cardiovascular diseases (34), neurological disorders (35) and metabolic diseases (36).

Recent data have revealed an important role for miRNA molecules performing either as pro-metastatic (oncogenes) or anti-metastatic (tumor suppressors) agents (37-39). Some miRNAs have been reported to be important prognostic markers for evaluating the stage or progression of diseases (40). A feature of a clinically-useful miRNA molecule as a biomarker should be at least that it is expressed in a cell type that is specifically involved in a certain disease process (23). Recent studies suggest that serum miRNA profiles may be useful as biomarkers of certain cancers (41). In fact, the relationship between miRNA dysregulation and cancer was only recognized in 2002 (42) and aberrant expression of miRNA molecules, particularly the ones circulating in serum, has been linked to cancer progression. Blood samples are easy to obtain and minimally invasive, making this source of mRNA attractive for exploring the role of potential circulating biomarkers (10). The identification and use of molecular biomarkers in cancer aims to increase the diagnostic accuracy and assist clinicians in the preoperative management of patients (43). As such, certain miRNA molecules can be useful with better estimating the prognosis of patients, predicting the efficacy of the therapeutic approach, better surveillance following surgery and planning in case of disease recurrence (10).

\section{MicroRNAs in Papillary Thyroid Carcinoma}

Thyroid Carcinoma (TC) is the most frequent endocrine malignancy, and affects mostly women (44). Incidences of this cancer are steadily increasing in many regions across the world over the years $(45,46)$. In 2018 alone, according to the Surveillance, Epidemiology and End Results Program (SEER) from the National Cancer Institute, - nearly 54,000 new cases of thyroid cancer were registered, accounting for $3.1 \%$ of all new cases of cancer during this year so far (47).

Thyroid cancers develop from abnormal parafollicular (medullary) and follicular cells (non-medullary) in over 95\% of all thyroid cancer (TC) cases. Four distinct clinical types of TC exist: i) papillary thyroid carcinoma (PTC), ii) follicular thyroid carcinoma (FTC), iii) medullary thyroid carcinoma (MTC), and iv) anaplastic thyroid carcinoma (ATC) (48). The most common type of TC is the papillary thyroid carcinoma (PTC) (49) followed by the follicular thyroid carcinoma (FTC). The anaplastic carcinoma is the most poorly differentiated, aggressive and invasive form of all types of TC, occurring in less than $2 \%$ of cases (50).

\section{Aberrant Expression of microRNA in Papillary Thyroid Carcinoma}

The relationship between miRNA dysregulation and cancer was recognized in 2002 (42), but the first published information of the role of miRNAs in thyroid tumorigenesis appeared in 2005 (51). Several miRNAs involved in PTC tumor initiation, progression and aggressiveness have been found abnormally expressed in serum/plasma or in tissue (up-regulated or down-regulated) (Table I) $(52,53)$.

\section{Circulating miRNAs in PTC}

A large number of studies have demonstrated that different levels of circulating miRNAs are associated with thyroid dysfunction. In 2012, Yu and coworkers demonstrated that levels of serum miRNA precursor Let-7e, as well as miR151-5p and miR-222 were significantly higher in the PTC group than in healthy controls or those with benign nodules (41). Yu et al., were the first to show that the levels of miR151-5p and miR-222 in serum decreased after thyroidectomy compared to the pre-operative status of patients (41). Furthermore, they confirmed that levels of these miRNA molecules are associated with cancer multifocality and increased tumor size, and advanced TNM stage (41). Not 
Table I. Expression of dysregulated miRNAs in papillary thyroid carcinoma.

\begin{tabular}{|c|c|c|c|}
\hline MicroRNA dysregulation & Sample type & Up-regulated/down-regulated & References \\
\hline MiR-31 & $\begin{array}{c}\text { Serum } \\
\text { Plasma } \\
\text { Tissue }\end{array}$ & Up-regulated & $\begin{array}{c}\text { Yoruker et al. (40) } \\
\text { Samsonov et al. (65) } \\
\text { Yip et al. (64) }\end{array}$ \\
\hline MiR-151-5p & Serum & Up-regulated & $\begin{array}{l}\text { Yoruker et al. (40) } \\
\text { Yu et al. (41) }\end{array}$ \\
\hline Let-7 & Serum & Up-regulated & Yoruker et al. (40) \\
\hline Let-7a & Tissue, thyroid cancer cell lines & Down-regulated & Zhou et al. (62) \\
\hline Let-7b & Tissue, thyroid cancer cell lines, serum & Up-regulated & $\begin{array}{l}\text { Li et al. (63) } \\
\text { Perdas et al. }(57)\end{array}$ \\
\hline Let-7e & Serum & Up-regulated & Yu et al. (41) \\
\hline MiR-21 & Serum & Down-regulated & Yoruker et al. (40) \\
\hline MiR-146a & Tissue & Up-regulated & Qiu et al. (76) \\
\hline MiR-146b & $\begin{array}{l}\text { Plasma } \\
\text { Serum } \\
\text { Tissue }\end{array}$ & Up-regulated & $\begin{array}{l}\text { Lee et al. }(20) \\
\text { Yip et al. }(64) \\
\text { Wei et al. }(84) \\
\text { Acibucu et al. }(75) \\
\text { Qiu } \text { et al. }(76) \\
\text { He et al. }(51) \\
\text { Pallante } \text { et al. }(73)\end{array}$ \\
\hline MiR-221 & $\begin{array}{l}\text { Serum } \\
\text { Tissue }\end{array}$ & Down-regulated & $\begin{array}{l}\text { Yoruker et al. (40) } \\
\text { Acibucu et al. (75) }\end{array}$ \\
\hline MiR-221-3p & Tissue & & $\begin{array}{l}\text { Chou et al. (74) } \\
\text { He et al. (51) }\end{array}$ \\
\hline MiR-222 & $\begin{array}{c}\text { Serum } \\
\text { Plasma } \\
\text { Tissue }\end{array}$ & Up-regulated & $\begin{array}{c}\text { Yorukeret al. }(40) \\
\text { Yu et al. }(41) \\
\text { Chou et al. }(74)\end{array}$ \\
\hline MiR-222-3p & Tissue & & $\begin{array}{l}\text { Acibucu et al. (75) } \\
\text { Lee et al. }(20) \\
\text { Yip et al. }(64) \\
\text { Chou et al. }(62) \\
\text { He } \text { et al. }(51) \\
\text { Pallante } \text { et al. }(73)\end{array}$ \\
\hline MiR-126 & Tissue & Down-regulated & $\begin{array}{c}\text { Xiong et al. }(66) \\
\text { Kitano et al. }(67) \\
\text { Wen et al. }(68) \\
\text { Qian } \text { et al. }(60)\end{array}$ \\
\hline MiR-7 & Tissue & Down-regulated & $\begin{array}{c}\text { Xiong et al. (66) } \\
\text { Kitano et al. (67) } \\
\text { Mancikova et al. } 70)\end{array}$ \\
\hline MiR-148-a & Tissue & Down-regulated & Han et al. (77) \\
\hline MiR-TG & Tissue & Down-regulated & Kolanowska et al. (71) \\
\hline
\end{tabular}

surprisingly, the levels of miR-151-5p and miR-222 appear to decrease following tumor excision (54). In the following year, Lee et al. came to similar conclusions. More specifically, they analyzed the levels of circulating miRNA before and after thyroidectomy in patients with or without recurrent PTC, and found that miR-222 and miR-146b present in plasma were reduced after total thyroidectomy in both groups (54). The researchers examined plasma instead of serum and the quantitative determination was made more than 2 weeks (from 2 to 6 weeks) after surgery (54).

Another group, Yoruker et al. analyzed a set of seven miRNA molecules in the serum of patients with PTC, multinodular goiter (enlarged thyroid) and in healthy controls (40). They noticed that Let-7 as well as miR-222, miR-31 and miR-151-5p levels were substantially higher in patients with PTC when compared to healthy controls and those with benign tumors, while miR-21 levels were lower. Furthermore, after thyroidectomy, miR-222 levels decreased dramatically in the PTC group, regardless of tumor size (40).

The Let-7 family is a very interesting group of miRNA precursors. Generally, the Let-7 family (Let-7a, Let-7b, Let7c, Let-7d, Let-7e, Let-7f, Let-7g and Let-7i) exhibit an important tumor suppressor activity in various cancers, including TC (55-61). The Let-7 family is considered as a 
tumor suppressor, since it inhibits the expression of several oncogenes, such as RAS, MYC, and HMGA2 in the thyroid tissue itself as well as in blood (serum or plasma) (41, 62, 63). Zhou et al. also demonstrated that Let-7a is significantly down-regulated in tissues of PTC patients as well as in TC cell lines (62). In addition, overexpression of Let-7a suppressed PTC cell proliferation, migration and invasion to distal sites. AKT2 was found to be a direct target of Let-7a and its expression levels inversely correlated to Let-7a expression in PTC tissues (62). Li et al. investigated the expression of Let-7b miRNA and high-mobility group A2 (HMGA2) mRNA in different PTC tissues and cell lines (PTC cell lines and normal human thyroid epithelial cell line) (63). They demonstrated that the expression of Let-7b was down-regulated, but the expression of HMGA2 was upregulated in thyroid tissues and cells compared to normal tissues and cells. Overexpression of Let-7b or knockdown of HMGA2 successfully suppressed the proliferation, migration, and invasion of PTC cells, while these effects were reversed by HMGA2 reintroduction. Moreover, Let-7b induced downregulation of HMGA2, and HMGA2 could affect the biological function of Let-7b in PTC cells, suggesting that Let-7b might function as a tumor suppressor in PTC (63).

MiR-31 is another miRNA molecule up-regulated in PTC and with significant role in the aggressiveness of this type of cancer (64). Samsonov et al. have demonstrated that high levels of MiR-31 were contained within exosomes in PTC patients prior to surgery, which were significantly reduced following the removal of the tumor (65). Similar results have been obtained for MiR-151, that has been found to be highly expressed in the blood (serum and plasma) of PTC patients compared to patients with benign thyroid tumors $(40,41)$.

Recently, Zhang et al. found that the expression levels of 3 miRNA molecules (miR-222, miR-221 and miR-146b) are much higher in patients with PTC compared to the healthy control group and to individuals with Benign Thyroid Nodules (BTN). High expression of these miRNAs was associated with certain poorer prognostic outcome as well as with PTC with recurrence (PTC-RC) (13).

MiR-126 is one of the miRNA molecules that when downregulated it appears to be associated with aggressive behavior of TC (66-69), while its overexpression inhibits the proliferation of TC cells and significantly reduces tumor growth and metastasis in vivo (66).

By developing a diagnostic technique using fine-needle aspiration thyroid biopsies, Kitano et al. identified four miRNA molecules differentially expressed between benign and malignant tumors, with low levels of miR-7 being the most precise diagnostic marker for thyroid carcinomas (67). Furthermore, Mancikova et al. have reported that papillary thyroid carcinomas with BRAF mutation, which is one of the most frequent ones in PTC, displayed an extreme downregulation of miR-7 and miR-204. The down-regulation of
miR-7 was also correlated to tumor aggressiveness (70). Similarly, a Polish group discovered that the down-regulation of a novel, functional microRNA encoded within the thyroglobulin gene (miR-TG) acting via the MAP kinase signaling, may also be a potential biomarker for PTC (71).

\section{Tissue miRNAs in PTC}

Specific patterns of several miRNA molecules detected in thyroid tumors of PTC patients correlate with clinicopathological features depending on, tumor size, status of multifocal lesion, capsular and vascular invasion, TNM stage and in some cases on the aggressiveness of the tumor (72). Studies by He and Pallante and their colleagues have shown a high expression of miR-146b-5p, miR-221-3p and miR-222-3p in papillary thyroid carcinomas $(51,73)$. One of the first studies to investigate the role of miRNAs in TC aggressiveness was published by Chou et al. (74). They demostrated that the expression of miR-146b, miR-221 and miR-222 were connected with extrathyroidal invasion and were higher in the high-risk PTC group compared to the lowrisk group. Furthermore, they demonstrated that expression of miR-146b in PTCs with BRAF mutation were much more higher compared to those without this mutation (74). Overexpression of the same miRNAs was found in papillary thyroid carcinoma patients with capsule and vascular invasion or lymph node metastasis, along with distant metastases (64). A study from Acibucu et al. revealed that the expression of miR-146b-5p, miR-221, miR-222 and p27Kip1, a member of the universal cyclin-dependent kinase inhibitor (CDKI) family, was higher in patients with distant metastases and lower levels of p27Kip1 and was associated with the aforementioned clinicopathological parameters in papillary TC (75). Similar results were obtained by Qiu et al. for miR-146a and miR 146b, who showed that these molecules appear to have an impact on the cancer cell proliferation and migration, as well as on regulation of IRAK1 (proteins which take part in one of the intracellular signaling control- TLRs/IL-1 signaling pathway) expression in cancer cells (76). In another study, Han et al. demonstrated that miR-148a negatively regulates PTC cell proliferation, migration, invasiveness, and tumor growth by down-regulating the expression of the target gene, cyclindependent kinase 8 (CDK8). Overexpression of miR-148a significantly represses expression of CDK8 by directly targeting the 3'-UTR of the $C D K 8$ gene in PTC tissues and in cell lines, while overexpression of $C D K 8$ reverses the inhibitory effects of miR-148a on PTC cell growth, migration and invasiveness (77). A meta-analysis of published studies comparing miRNA expression data in invasive thyroid carcinoma compared to non-invasive tumors or normal tissues by a Chinese group showed 29 dysregulated miRNAs associated with TC in 6 studies (78). 
Findings illustrate that miRNAs have been deregulated in TC and moreover they have been demonstrated to function as tumor suppressors and as oncogenes, as well. These molecules are key regulators of thyroid cell function, and influence thyroid hormone production and cell proliferation. As mentioned previously, the expression of miRNAs is strictly tissue-specific and, during pathological conditions, alterations in miRNA expression can cause loss-of-function and tumorigenesis in thyroid cells $(32,79)$. In summary, overexpression of certain miRNAs can result in inhibition of some tumor suppressor genes and down-regulation of certain miRNAs can lead to increased expression of oncogenes, leading to tumor growth and progression in PTC (52).

\section{MicroRNA Single Nucleotide Polymorphism in Papillary Thyroid Carcinoma}

The role of miRNA can be greatly affected by single nucleotide polymorphisms (SNPs), since these variations can change miRNA affinity to particular transcripts, while they may also produce novel miRNA-specific binding sites or destroy them (80). Polymorphisms in microRNA may therefore have a distinct impact on gene and protein expression that can influence the risk of developing or the progression of some diseases, such as PTC (81), since an SNP located within the miRNA mature sequence or within the seed region of the mature miRNA sequence (1) may modify its normal function. Such is the case of a common ( $>1 \%$ in at least one population) SNP in pre-miR-146a that can inhibit mature miRNA expression and boost the risk of developing PTC $(51,82)$.

The first evidence proving that the SNP played an important role in PTC progression was demonstrated in 2005 by $\mathrm{He}$ et al. The group sequenced the regions harboring two miRNA-binding sites in the KIT gene from PTC patients and found that the G>A SNP is located within the KIT 3' UTR, complementary to the seed region of miR-221/222, while the $\mathrm{G}>\mathrm{C}$ SNP in exon 18 is located within the site complementary to the seed region of miR-146a/146b. These two SNPs have been linked to dysregulated expression of the KIT protein and may have a causative role in the development of PTC (51). Jażdżewski et al. also found that a common SNP within the pre-miR-146a sequence weakens its maturation and leads to reduced mRNA target recognition. This SNP-related reduction of miR-146a expression has been implicated in PTC (82), with high risk of PTC confirmed in both North American and European populations $(82,83)$. In addition, this SNP in a heterozygous state (GC) differs from either GC or CC homozygotes by producing 3 mature miRNAs. These modulate genes mainly involved in the regulation of apoptosis, causing an exaggerated DNA-damage response, and thus more severe consequences in heterozygotes than in homozygotes (84). A new somatic mutation (c.5438A>G; E1813G) within the DICERl gene was discovered by Penha et al., who showed an up-regulation ofDICER1 expression in human TC cells of PTC (TPC-1, BCPAP, FRO and 8505c) and anaplastic thyroid carcinoma samples. XPO5, as mentioned previously, is a miRNA-related nuclear export protein, and its dysfunction may cause the dysregulation of miRNAs and contribute to carcinogenesis (85). Wen et al. showed that the expression of XPO5 in TC tissues was significantly lower than in normal tissues and XPO5 expression was dependent on the XPO5 SNP rs11077. Furthermore, G allele of rs11077 was strongly associated with low expression of XPO5 in TC patients, thus providing a potential marker for TC diagnosis (86).

Finally, a novel network application, called Rank miRNA, helps analyze the impact of genomic variations on miRNAtarget interactions. This can also be used to predict the impact of SNPs on miRNA-mRNA binding capability and identify target genes of (possibly new) miRNA molecules based on their sequences (80).

Taken together, all these studies indicate that SNPs located within the binding sites of miRNA molecules may affect the expression of their target genes and as such, influence the development or progression of PTC.

\section{Conclusion}

This review provides a brief overview of the regulation and different roles of miRNAs in PTC. MiRNAs might be especially useful tools in diagnosis, prognosis and prediction of recurrence of PTC since many are deregulated in PTC. As it was presented in this review, the molecular epidemiology of PTC is also associated with polymorphisms of miRNA genes, which can affect the expression of miRNAs and subsequently affect the expression of their target genes.

More studies on specific miRNA expression in the thyroid are required for the identification of new sequences and delineation of their role in the development and progression of PTC. Serum miRNA profiling may be one of the best methods to further expand our knowledge on this subject.

\section{Ethical Approval}

This article does not contain any studies with human participants or animals performed by any of the authors.

\section{References}

1 Bartel DP: MicroRNAs: genomics, biogenesis, mechanism, and function. Cell 116: 281-297, 2004.

2 Huntzinger E and Izaurralde E: Gene silencing by microRNAs: contributions of translational repression and mRNA decay. Nat Rev Genet 12: 99-110, 2011.

3 Ipsaro JJ and Joshua-Tor L: From guide to target: molecular insights into eukaryotic RNA-interference machinery. Nat Struct Mol Biol 22: 20-28, 2015. 
4 Zhang J, Zhou W, Liu Y, Liu T, Li C and Wang L: Oncogenic role of microRNA-532-5p in human colorectal cancer via targeting of the 5'UTR of RUNX3. Oncol Lett 15: 7215-7220, 2018.

5 Zhang B, Pan X, Cobb GP and Anderson TA: microRNAs as oncogenes and tumor suppressors. Dev Biol 302: 1-12, 2007.

6 Latini A, Ciccacci C, Novelli G and Borgiani P: Polymorphisms in miRNA genes and their involvement in autoimmune diseases susceptibility. Immunol Res 65: 811-827, 2017.

7 Decmann Á, Perge P, Nagy Z, Butz H, Patócs A and Igaz P: Circulating microRNAs in the diagnostics of endocrine neoplasms. Orv Hetil 158: 483-490, 2017.

8 Swarup V and Rajeswari MR: Circulating (cell-free) nucleic acids - A promising, non-invasive tool for early detection of several human diseases. FEBS Lett 581: 795-799, 2007.

9 Hanson EK, Lubenow $\mathrm{H}$ and Ballantyne J: Identification of forensically relevant body fluids using a panel of differentially expressed microRNAs. Anal Biochem 387: 303-314, 2009.

10 Wittmann $J$ and Jäck H-M: Serum microRNAs as powerful cancer biomarkers. Biochim Biophys Acta - Reviews on Cancer 1806: 200-207, 2010.

11 Raposo G and Stoorvogel W: Extracellular vesicles: exosomes, microvesicles, and friends. J Cell Biol 200: 373-386, 2013.

12 Chen X, Ba Y, Ma L, Cai X, Yin Y, Wang K, Guo J, Zhang Y, Chen J, Guo X, Li Q, Li X, Wang W, Zhang Y, Wang J, Jiang X, Xiang Y, Xu C, Zheng P, Zhang J, Li R, Zhang H, Shang X, Gong $\mathrm{T}$, Ning $\mathrm{G}$, Wang $\mathrm{J}$, Zen $\mathrm{K}$, Zhang $\mathrm{J}$ and Zhang $\mathrm{CY}$ : Characterization of microRNAs in serum: a novel class of biomarkers for diagnosis of cancer and other diseases. Cell Research 18: 997-1006, 2008.

13 Zhang Y, Xu D, Pan J, Yang Z, Chen M, Han J, Zhang S, Sun L and Qiao H: Dynamic monitoring of circulating microRNAs as a predictive biomarker for the diagnosis and recurrence of papillary thyroid carcinoma. Oncol Lett 13: 4252-4266, 2017.

14 Kim VN, Han J and Siomi MC: Biogenesis of small RNAs in animals. Nat Rev Mol Cell Biol 10: 126-139, 2009.

15 Lee Y, Kim M, Han J, Yeom KH, Lee S, Baek SH and Kim VN: MicroRNA genes are transcribed by RNA polymerase II. EMBO J 23: 4051-4060, 2004

16 Denli AM, Tops BBJ, Plasterk RHA, Ketting RF and Hannon GJ: Processing of primary microRNAs by the microprocessor complex. Nature 432: 231-235, 2004.

17 Han J, Lee Y, Yeom KH, Nam JW, Heo I, Rhee JK, Sohn SY, Cho Y, Zhang BT and Kim VN: Molecular basis for the recognition of primary microRNAs by the drosha-DGCR 8 complex. Cell 125: 887-901, 2006.

18 Bartel DP: MicroRNAs: target recognition and regulatory functions. Cell 136: 215-233, 2009.

19 Miska EA: How microRNAs control cell division, differentiation and death. Curr Opin Genet Dev 15: 563-568, 2005.

20 Lee RC, Feinbaum RL and Ambros V: The $C$. elegans heterochronic gene lin- 4 encodes small RNAs with antisense complementarity to lin-14. Cell 75: 843-854, 2005.

21 Griffiths-Jones S: miRBase: The microRNA sequence database. Methods Biol Mol 342: 129-138, 2006.

22 Mitchell PS, Parkin RK, Kroh EM, Fritz BR, Wyman SK, Pogosova-Agadjanyan EL, Peterson A, Noteboom J, O'Briant KC, Allen A, Lin DW, Urban N, Peterson A, Noteboom J, O'Briant KC, Allen A, Lin DW, Urban N, Drescher CW, Knudsen BS, Stirewalt DL, Gentleman R, Vessella RL, Nelson
PS, Martin DB and Tewari M: Circulating microRNAs as stable blood-based markers for cancer detection. Proc Natl Acad Sci USA 105: 10513-10518, 2008.

23 Haider BA, Baras AS, McCall MN, Hertel JA, Cornish TC and Halushka MK: A critical evaluation of microRNA biomarkers in non-neoplastic disease. PLoS ONE 9: e89565, 2014.

24 miRBase: the microRNA database website. Available: http:// www.mirbase.org/. (Accessed August 10, 2018)

$25 \mathrm{Lu}$ J, Getz G, Miska EA, Alvarez-Saavedra E, Lamb J, Peck D, Sweet-Cordero A, Ebert BL, Mak RH, Ferrando AA, Downing JR, Jacks T, Horvitz HR and Golub TR: MicroRNA expression profiles classify human cancers. Nature 435: 834$838,2005$.

26 Deng X, Su Y, Wu H, Wu R, Zhang P, Dai Y, Chan TM, Zhao $\mathrm{M}$ and $\mathrm{Lu} \mathrm{Q}$ : The role of microRNAs in autoimmune diseases with skin involvement. Scand J Immunol 81: 153-165, 2015.

27 Murata K, Yoshitomi H, Tanida S, Ishikawa M, Nishitani K, Ito $\mathrm{H}$ and Nakamura T: Plasma and synovial fluid microRNAs as potential biomarkers of rheumatoid arthritis and osteoarthritis. Arthritis Res Ther 12: R86, 2010.

28 Krissansen GW, Yang Y, McQueen FM, Leung E, Peek D, Chan YC, Print $C$, Dalbeth $N$, Williams $M$ and Fraser AG: Overexpression of miR-595 and miR-1246 in the sera of patients with active forms of inflammatory bowel disease. Inflamm Bowel Dis 21: 520-530, 2015.

29 Croce CM and Calin GA: miRNAs, cancer, and stem cell division. Cell 122: 6-7, 2005.

30 Simons M and Raposo G: Exosomes - vesicular carriers for intercellular communication. Curr Opin Cell Biol 21: 575-581, 2009.

31 Lin J, Li J, Huang B, Liu J, Chen X, Chen X-M,Xu Y-M,Huang L-F and Wang X-Z: Exosomes: Novel biomarkers for clinical diagnosis. Scientific World Journal 2015: 657086, 2015.

32 Barbarotto E, Schmittgen TD and Calin GA: MicroRNAs and cancer: Profile, profile, profile. Int J Cancer 122: 969-977, 2007.

33 Gilad S, Meiri E, Yogev Y, Benjamin S, Lebanony D, Yerushalmi $\mathrm{N}$, Benjamin H, Kushnir M, Cholakh H, Melamed N, Bentwich Z, Hod M, Goren Y and Chaju A: Serum microRNAs are promising novel biomarkers. PLoS ONE 3: e3148, 2008.

34 Sayed ASM, Xia K, Li F, Deng X, Salma U, Li T, Deng H, Yang $\mathrm{D}$, Haoyang Z, Yang $\mathrm{T}$ and Peng J: The diagnostic value of circulating microRNAs for middle-aged (40-60-year-old) coronary artery disease patients. Clinics 70: 257-263, 2015.

35 Kumar P, Dezso Z, MacKenzie C, Oestreicher J, Agoulnik S, Byrne M, Bernier F, Yanagimachi M, Aoshima K and Oda Y: Circulating miRNA biomarkers for Alzheimer's disease. PLoS ONE 8: e69807, 2013.

36 Rong Y, Bao W, Shan Z, Liu J, Yu X, Xia S, Gao H, Wang X, Yao P, Hu FB and Liu L: Increased microRNA-146a levels in plasma of patients with newly diagnosed type 2 diabetes mellitus. PLoS ONE 8: e73272, 2013.

37 Lima CR, Gomes CC and Santos MF: Role of microRNAs in endocrine cancer metastasis. Mol Cell Endocrinol 456: 62-75, 2017.

38 Pallasch CP, Patz M, Park YJ, Hagist S, Eggle D, Claus R, Debey-Pascher S, Schulz A, Frenzel LP, Claasen J, Kutsch N, Krause G, Mayr C, Rosenwald A, Plass C, Schultze JL, Hallek $\mathrm{M}$ and Wendtner CM: miRNA deregulation by epigenetic silencing disrupts suppression of the oncogene PLAG1 in chronic lymphocytic leukemia. Blood 114: 3255-3264, 2009. 
39 You Y, Tan JX, Dai HS, Chen HW, Xu XJ, Yang AG, Zhang YJ, Bai LH and Bie P: MiRNA-22 inhibits oncogene galectin-1 in hepatocellular carcinoma. Oncotarget 7: 57099-57116, 2016.

40 Yoruker EE, Terzioglu D, Teksoz S, Uslu FE, Gezer U and Dalay N: MicroRNA Expression profiles in papillary thyroid carcinoma, benign thyroid nodules and healthy controls. J Cancer 7: 803-809, 2016.

41 Yu S, Liu Y, Wang J, Guo Z, Zhang Q, Yu F, Zhang Y, Huang $\mathrm{K}$, Li Y, Song E, Zheng $\mathrm{X}$ and Xiao $\mathrm{H}$ : Circulating microRNA profiles as potential biomarkers for diagnosis of papillary thyroid carcinoma. J Clin Endocrinol Metab 97: 2084-2092, 2012.

42 Calin GA, Dumitru CD, Shimizu M, Bichi R, Zupo S, Noch E, Aldler H, Rattan S, Keating M, Rai K, Rassenti L, Kipps T, Negrini $\mathrm{M}$, Bullrich $\mathrm{F}$ and Croce $\mathrm{CM}$ : Nonlinear partial differential equations and applications: Frequent deletions and down-regulation of microRNA genes miR15 and miR16 at 13q14 in chronic lymphocytic leukemia. Proc Natl Acad Sci USA 99: 15524-15529, 2002.

43 Moore MD, Panjwani S, Gray KD, Finnerty BM, Zarnegar R and Fahey TJ: The role of molecular diagnostic testing in the management of thyroid nodules. Expert Rev Mol Diagn 17: 567576, 2017.

44 Xia Q, Dong S, Bian PD, Wang J and Li CJ: Effects of endocrine therapy on the prognosis of elderly patients after surgery for papillary thyroid carcinoma. Eur Arch Otorhinolaryngol 273: 1037-1043, 2016.

45 Ferlay J, Soerjomataram I, Dikshit R, Eser S, Mathers C, Rebelo M, Parkin DM, Forman D and Bray F: Cancer incidence and mortality worldwide: Sources, methods and major patterns in GLOBOCAN 2012. Int J Cancer 136: E359-E386, 2017.

46 Nikiforov YE and Nikiforova MN: Molecular genetics and diagnosis of thyroid cancer. Nat Rev Endocrinol 7: 569-580, 2011.

47 Cancer Stat Facts: Thyroid Cancer website. Available: https:// seer.cancer.gov/statfacts/html/thyro.html. (Accessed September 20, 2018)

48 Mazzaferri EL: An overview of the management of papillary and follicular thyroid carcinoma. Thyroid 9: 421-427, 1999.

49 Das S, Chaudhary N, Ang L-C and Megyesi JS: Papillary thyroid carcinoma metastasizing to anaplastic meningioma: an unusual case of tumor-to-tumor metastasis. Brain Tumor Pathol 34: 130-134, 2017.

50 Aschebrook-Kilfoy B, Ward MH, Sabra MM and Devesa SS: Thyroid cancer incidence patterns in the United States by histologic type, 1992-2006. Thyroid 21: 125-134, 2011.

$51 \mathrm{He}$ H, Jazdzewski K, Li W, Liyanarachchi S, Nagy R, Volinia SE, Calin GA, Liu CG, Franssila K, Suster S, Kloos RT, Croce $\mathrm{CM}$ and de la Chapelle A: The role of microRNA genes in papillary thyroid carcinoma. Proc Natl Acad Sci USA 102: 19075-19080, 2005.

52 Pishkari S, Paryan M, Hashemi M, Baldini E and MohammadiYeganeh S: The role of microRNAs in different types of thyroid carcinoma: a comprehensive analysis to find new miRNA supplementary therapies. J Endocrinol Invest 41: 269-283, 2018.

53 Chruścik A and Lam AK: Clinical pathological impacts of microRNAs in papillary thyroid carcinoma: A crucial review. Exp Mol Pathol 99: 393-398, 2015.

54 Lee JC, Zhao JT, Clifton-Bligh RJ, Gill A, Gundara JS, Ip JC, Glover A, Sywak MS, Delbridge LW, Robinson BG and Sidhu SB: MicroRNA-222 and MicroRNA-146b are tissue and circulating biomarkers of recurrent papillary thyroid cancer. Cancer 119: 4358-4365, 2013.
55 Ricarte-Filho JCM, Fuziwara CS, Yamashita AS, Rezende E, daSilva MJ and Kimura ET: Effects of Let-7 microRNA on cell growth and differentiation of papillary thyroid cancer. Transl Oncol 2: 236-241, 2009.

56 Damanakis AI, Eckhardt S, Wunderlich A, Roth S, Wisniowski TT, Bartsch DK and Di Fazio P: MicroRNAs let7 expression in thyroid cancer: correlation with their deputed targets HMGA2 and SLC5A5. J Cancer Res Clin Oncol 142: 1213-1220, 2016.

57 Perdas E, Stawski R, Nowak D and Zubrzycka M: The Role of miRNA in papillary thyroid cancer in the context of miRNA Let7 family. Int J Mol Sci 17: 909, 2016.

58 Cho S, Mutlu L, Grechukhina O and Taylor HS: Circulating microRNAs as potential biomarkers for endometriosis. Fertil Steril 103: 1252-1260, 2015.

59 Calin GA and Croce CM: MicroRNA signatures in human cancers. Nat Rev Cancer 11: 857-866, 2006.

60 Corsini LR, Bronte G, Terrasi M, Amodeo V, Fanale D, Fiorentino E, Cicero G, Bazan V and Russo A: The role of microRNAs in cancer: Diagnostic and prognostic biomarkers and targets of therapies. Expert Opin Ther Targets 16: 103-109, 2012.

61 Wang X, Cao L, Wang Y, Wang X, Liu N and You Y: Regulation of let-7 and its target oncogenes (Review). Oncol Lett 3: 955960, 2012.

62 Zhou B, Shan H, Su Y, Xia K, Zou R and Shao Q: Let-7a inhibits migration, invasion and tumor growth by targeting AKT2 in papillary thyroid carcinoma. Oncotarget 8: 69746-69755, 2017.

$63 \mathrm{Li} \mathrm{H}$, Zhao L, Zhang Z, Zhang H, Ding C and Su Z: Roles of microRNA Let- $7 b$ in papillary thyroid carcinoma by regulating HMGA2. Tumor Biol 39: 101042831771927, 2017.

64 Yip L, Kelly L, Shuai Y, Armstrong MJ, Nikiforov YE, Carty SE and Nikiforova MN: MicroRNA signature distinguishes the degree of aggressiveness of papillary thyroid carcinoma. Ann Surg Oncol 18: 2035-2041, 2011.

65 Samsonov R, Burdakov V, Shtam T, Radzhabova Z, Vasilyev D, Tsyrlina E, Titov S, Ivanov M, Berstein L, Filatov M, Kolesnikov N, Gil-Henn H and Malek A: Plasma exosomal miR21 and miR-181a differentiates follicular from papillary thyroid cancer. Tumor Biol 37: 12011-12021, 2016.

66 Xiong Y, Kotian S, Zeiger MA, Zhang L and Kebebew E: miR126-3p inhibits thyroid cancer cell growth and metastasis, and is associated with aggressive thyroid cancer. PLOS ONE 10: e0130496, 2015.

67 Kitano M, Rahbari R, Patterson EE, Xiong Y, Prasad NB, Wang Y, Zeiger MA and Kebebew E: Expression profiling of difficultto-diagnose thyroid histologic subtypes shows distinct expression profiles and identify candidate diagnostic microRNAs. Ann Surg Oncol 18: 3443-3452, 2011.

68 Wen Q, Zhao J, Bai L, Wang T, Zhang H and Ma Q: miR-126 inhibits papillary thyroid carcinoma growth by targeting LRP6. Oncol Rep 34: 2202-2210, 2015.

69 Qian Y, Wang X, Lv Z, Gup C, Yang Y, Zhang J and Wang X: MicroRNA-126 is downregulated in thyroid cancer cells, and regulates proliferation, migration and invasion by targeting CXCR4. Mol Med Rep 14: 453-459, 2016.

70 Mancikova V, Castelblanco E, Pineiro-Yanez E, Perales-Paton J, de Cubas AA, Inglada-Perez L, Matias-Guiu X, Capel I, Bella M, Lerma E, Riesco-Eizaguirre G, Santisteban P, Maravall F, Mauricio D, Al-Shahrour F and Robledo M: MicroRNA deepsequencing reveals master regulators of follicular and papillary thyroid tumors. Mod Pathol 28: 748-757, 2015. 
71 Kolanowska M, Wójcicka A, Kubiak A, Świerniak M, Kotlarek M, Maciąg M, Gaj P, Koperski Ł, Gornicka B and Jazdzewski $\mathrm{K}$ : Functional analysis of a novel, thyroglobulin-embedded microRNA gene deregulated in papillary thyroid carcinoma. Sci Rep 7: 9942, 2017.

72 Celano M, Rosignolo F, Maggisano V, Pecce V, Iannone M, Russo D and Bulotta S: MicroRNAs as biomarkers in thyroid carcinoma. Int J Genomics 2017: 6496570, 2017.

73 Pallante P, Visone R, Ferracin M, Ferraro A, Berlingieri MT, Troncone G, Chiappetta G, Liu CG, Santoro M, Negrini M, Croce $\mathrm{CM}$ and Fusco A: MicroRNA deregulation in human thyroid papillary carcinomas. Endocr Relat Cancer 13: 497-508, 2006.

74 Chou CK, Chen RF, Chou FF, Chang HW, Chen YJ, Lee YF, Yang KD, Cheng JT, Huang CC and Liu RT: miR-146b is highly expressed in adult papillary thyroid carcinomas with high risk features including extrathyroidal invasion and the BRAF V600 Emutation. Thyroid 20: 489-494, 2010.

75 Acibucu F, Dökmetaș H, Tutar Y, Elagoz S and Kilicli F: Correlations between the expression levels of micro-RNA 146b, 221, 222 and p27Kip1 protein mRNA and the clinicopathologic parameters in papillary thyroid cancers. Exp Clin Endocrinol Diabetes 122: 137-143, 2014

76 Qiu Z, Li H, Wang J and Sun C: miR-146a and miR-146b in the diagnosis and prognosis of papillary thyroid carcinoma. Oncol Rep 38: 2735-2740, 2017.

77 Han C, Zheng W, Ge M, Wang K, Xiang Y and Wang P: Downregulation of cyclin-dependent kinase 8 by microRNA148a suppresses proliferation and invasiveness of papillary thyroid carcinomas. Am J Cancer Res 7: 2081-2090, 2017.

78 Wang T, Xu H, Qi M, Tian X and Tian X: miRNA dysregulation and the risk of metastasis and invasion in papillary thyroid cancer: a systematic review and meta-analysis. Oncotarget 9: 5473-5479, 2017
79 Fuziwara CS and Kimura ET: MicroRNAs in thyroid development, function and tumorigenesis. Mol Cell Endocrinol 456: 444-50, 2017.

80 Beretta S, Maj C and Merelli I: Rank miRNA: a web tool for identifying polymorphisms altering miRNA target sites. Procedia Comput Sci 108: 1125-1134, 2017.

81 Chen K, Song F, Calin GA, Wei Q, Hao X and Zhang W: Polymorphisms in microRNA targets: a gold mine for molecular epidemiology. Carcinogenesis 29: 1306-1311, 2008.

82 Jazdzewski K, Murray EL, Franssila K, Jarzab B, Schoenberg DR and de la Chapelle A: Common SNP in pre-miR-146a decreases mature miR expression and predisposes to papillary thyroid carcinoma. Proc Natl Acad Sci USA 105: 7269-7274, 2008

83 de la Chapelle A and Jazdzewski K: MicroRNAs in thyroid cancer. J Clin Endocrinol Metab 96: 3326-3336, 2011.

84 Wei WJ, Wang YL, Li DS, Wang Y, Wang XF, Zhu YX,Yang YJ, Wang ZY, Ma YV, Wu Y, Jin L, Ji OH and Wang JC: Association between the rs2910164 polymorphism in pre-mir-146a sequence and thyroid carcinogenesis. PLOS ONE 8: e56638, 2013.

85 Peng $\mathrm{Y}$ and Croce $\mathrm{CM}$ : The role of microRNAs in human cancer. Signal Transduc Target Ther 1: 15004, 2016.

86 Wen J, Gao Q, Wang N, Zhang W, Cao K, Zhang Q, Chen S and Shi L: Association of microRNA-related gene XPO5 rs11077 polymorphism with susceptibility to thyroid cancer. Medicine 96: e6351, 2017
Received October 16, 2018

Revised November 19, 2018

Accepted November 23, 2018 